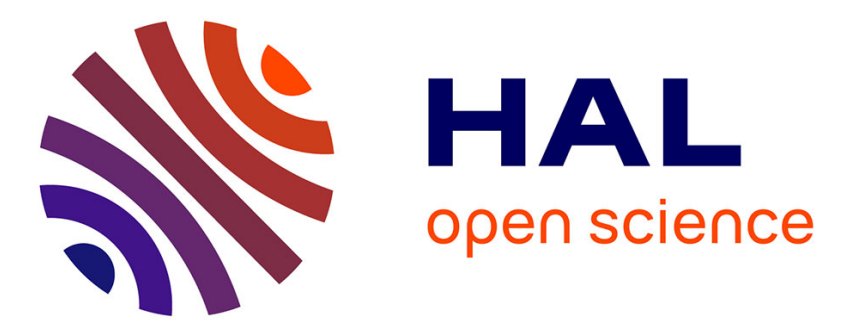

\title{
Structural, AMS and geochronological study of a laccolith emplaced during Late Variscan orogenic extension: the Rocles pluton (SE French Massif Central)
}

Eugène Be Mezeme, Michel Faure, Yan Chen, Alain Cocherie, Jean-Yves Talbot

\section{To cite this version:}

Eugène Be Mezeme, Michel Faure, Yan Chen, Alain Cocherie, Jean-Yves Talbot. Structural, AMS and geochronological study of a laccolith emplaced during Late Variscan orogenic extension: the Rocles pluton (SE French Massif Central). International Journal of Earth Sciences, 2006, 96 (2), pp.215-228. 10.1007/s00531-006-0098-2 . hal-00089183

\section{HAL Id: hal-00089183 \\ https://hal-insu.archives-ouvertes.fr/hal-00089183}

Submitted on 9 May 2007

HAL is a multi-disciplinary open access archive for the deposit and dissemination of scientific research documents, whether they are published or not. The documents may come from teaching and research institutions in France or abroad, or from public or private research centers.
L'archive ouverte pluridisciplinaire HAL, est destinée au dépôt et à la diffusion de documents scientifiques de niveau recherche, publiés ou non, émanant des établissements d'enseignement et de recherche français ou étrangers, des laboratoires publics ou privés. 


\title{
Structural, AMS and geochronological study of a laccolith emplaced during Late Variscan orogenic extension: the Rocles pluton (SE French Massif Central)
}

\author{
E. Be Mezeme ${ }^{1,2}$, M. Faure ${ }^{1}$, Y. Chen ${ }^{1}$, A. Cocherie $^{2}$ and J-Y. Talbot ${ }^{1}$ \\ (1) Institut des Sciences de la Terre d'Orléans (ISTO), UMR CNRS 6113, Bâtiment \\ Géosciences, Université d'Orléans, BP 6759, 45067 Orléans cedex 2, France \\ (2) BRGM, Av. Claude-Guillemin, BP 6009, 45060 Orléans cedex 2, France
}

\begin{abstract}
In the southern French Massif Central, the Rocles leucogranite of Variscan age consists of three petrographic facies; textural analysis shows that they experienced the same subsolidus deformation. New chemical U-Th-Pb dating on monazite yielded $324 \pm 4 \mathrm{Ma}$ and $325 \pm 5 \mathrm{Ma}$ ages for muscovite-rich and biotite-rich facies respectively. AMS-study results agree with petrostructural observations. The magnetic planar and linear fabrics, which correspond to the preferred orientation of biotite and muscovite, are consistent with the foliation and lineation defined by the preferred mineral orientation. This fabric developed during pluton emplacement. The accordance of this granite foliation with that observed in the host rock, suggests that the Rocles pluton is a laccolith, but its present geometry resulted from postemplacement southward tilting due to the uplift of the Late Carboniferous Velay dome. Restoration of the primary geometry of the pluton and its country-rocks to a flat-lying attitude places the granite lineation close to the trend measured in other plutons of the area. This restoration further supports the interpretation of the Rocles laccolith as a pluton emplaced along a tectonic contact reactivated during the late-orogenic collapse of the Variscan Belt.
\end{abstract}

Keywords : Syntectonic pluton - Extensional tectonics - AMS fabric - Variscan Belt - French Massif Central

\section{Introduction}

It is widely acknowledged that the development of planar and linear fabrics in granitic plutons results from the interplay between magma dynamics during its crystallisation and regional tectonics during pluton emplacement. In collision orogens, crustal melting commonly takes place after thickening, during the crustal thinning stage of the belt. Thus the architecture of crustal-derived plutons generally records the extensional tectonic setting coeval with collapse of the orogen (e.g. Hutton et al. 1990; Fowler 1994; Scaillet et al. 1995). However, compressional or wrench settings are also developed (e.g. Roman-Berdiel et al. 1998; Brown and Solar 1998; Bouchez 1997 and enclosed references).

In the French Variscan Belt, it has been argued that the Middle to Late Carboniferous magmatism developed after the Early Carboniferous nappe stacking during late-orogenic collapse (Faure 1995; Faure et al. 2004 and references therein). Nevertheless, some plutons may have been emplaced earlier in the orogenic evolution, during thrusting (Duguet and Faure 2004). In the southeastern Massif Central (Cévennes area), most monzogranites and two-mica leucogranites were emplaced during the Middle Carboniferous (ca. 325-315 Ma) after nappe stacking (e.g. Faure et al. 2001; Talbot et al. 2000, 2004). Furthermore, in the northern part of the study area, several leucogranite bodies are exposed along a major contact between two tectonic units, the kilometre-sized Rocles leucogranite being the largest of these 
bodies. Therefore, the question arises whether this pluton was emplaced during or after thrusting. This study investigates the petrology and structure of the weakly deformed Rocles leucogranite pluton using the AMS technique. New U-Th-Pb ages presented below support an emplacement timing coeval with neighbouring plutons. A tectonic evolution model for the Rocles pluton with its country rocks is proposed.

\section{Regional geological setting}

Paleozoic tectonic evolution of the French Massif Central was the result of continental collision between the Gondwana and Laurasia supercontinents (e.g. Matte 1986). In the southern part of the Massif Central, intracontinental shortening yielded southward ductile and synmetamorphic shearing responsible for nappe stacking (Ledru et al. 1989; Faure et al. 1997) dated at 340-330 Ma by ${ }^{40} \mathrm{Ar} /{ }^{39} \mathrm{Ar}$ geochronology on muscovite, biotite and amphibole (Caron 1994). This Middle Carboniferous (Visean) southward thrusting, characterised by a flat-lying or north dipping foliation and a N-S to NE-SW trending lineation, is often compared with Himalayan tectonics (Mattauer and Echecopar 1977; Matte 1986). Immediately after thickening, the country rocks (metapelite, metagrauwacke and gneiss) underwent conspicuous melting during the Middle to Late Carboniferous (Duthou et al. 1984; Pin and Duthou 1990); this resulted in numerous peraluminous granitic and monzogranitic plutons in the Massif Central that were emplaced coevally with the late-orogenic extensional tectonics at about 325-310 Ma. The crustal thinning was controlled by NW-SE to E-W trending stretching, well represented by mineral and stretching lineations in both plutons and host rocks (Faure 1995). The granites thus preserved structural evidence of their tectonic setting, providing a key for understanding the regional structural evolution of the Variscan Belt.

In the Cévennes area, diverse leucogranite and monzogranite bodies occur of various shape and size, ranging from decametre-wide vein sheets to the multi-kilometre-wide Margeride and Mt-Lozère-La Borne batholiths. The Rocles massif is a WSW-ENE-elongated peraluminous granite body of about 10-km length (Fig. 1), exposed in the northeastern Cévennes. The granite is in tectonic contact to the south with the overlying Cévennes micaschist-quartzite series, metamorphosed under greenschist to lower amphibolite facies, and the underlying orthogneiss and paragneiss to the north (Palm 1957; Weisbrod 1968). Its eastern contact with country rocks is hidden below Permian and Mesozoic sedimentary rocks. To the west of the Rocles massif, numerous decametre-sized leucogranite veins, locally with a mylonitic fabric, are common along the tectonic contact between micaschist and gneiss. However, their small size does not allow them to be shown on the map (Fig. 1). As shown below, their petrological features and radiometric age show that these veins are genetically related to the Rocles pluton. Numerous metre-scale leucogranite dykes and sills are widely distributed in the micaschist that forms the hanging wall of the pluton (Fig. 2). Due to their petrological resemblance, it is likely that these dykes and lenses are part of the Rocles granite. Farther north, Late Carboniferous cordierite-bearing granite and migmatite of the Velay dome are exposed (e.g. Ledru et al. 2001 and references therein). The gneisses below the Cévennes micaschist are conspicuously migmatised. A crustal melting interpreted by some authors (e.g. Ledru et al. 2001; Montel et al. 1992; Barbey et al. 1999) as belonging to the Velay dome process, these migmatites are in fact older and petrologically different. Field evidence and petrology show that the Cévennes cordierite-free migmatite is distinct from the Velay cordierite-bearing migmatite. Recent chemical U-Th-Pb dating on leucosomes indicated Middle Carboniferous (ca. 330-325 Ma) ages (Be Mezeme et al. 2005). Besides, Mougeot et al. 1997 determined an age of about $314 \pm 5 \mathrm{Ma}$ using isotopic dating of monazite extracted from migmatitic gneiss that could correspond to Cévennes migmatites. The authors collected samples in the Velay dome, the age of $314 \pm 5$ Ma seems younger. It can be due to: (1) the increase of temperature in the dome liable to disturb monazite geochronometer. The authors already pinpointed the 
possible episodic lead loss and reported different generation of monazite with variable composition and with common inheritance. In this case of working on possible polygenic minerals extracted from the host rock, it can be quite difficult to ascertain the origin of grains and interpret the result. (2) The common inheritance can induce mixture of domains of different ages. To avoid such disruptions we experienced new way of dating monazite using electron probe. Three samples of Cévennes migmatites collected at three different places were analysed directly within thin sections to ease age interpretations. These samples yield ages at around 325-330 Ma we interpreted as age of migtisation process that preceded the orogenic extension.

Due to its peculiar location along a tectonic contact, a structural study has been undertaken in order to assess the tectonic setting of the Rocles pluton. On the following pages, we argue that it is a Middle Carboniferous synkinematic body emplaced along a polyphase crustal discontinuity during late-orogenic extensional tectonics.

\section{Petrography and geochemistry of Rocles granite Petrographic overview}

The Rocles pluton consists of three petrological facies defined by their relative amounts of biotite and muscovite (Palm 1957; Weisbrod 1968). Muscovite-rich rocks crops out along the southern and south-eastern margins of the pluton (Fig. 1). A porphyritic biotite-rich facies occupies the northern and largest part of the massif. An intermediate facies of biotitemuscovite leucogranite is found at the western and the eastern ends of the pluton. The biotite granite contains numerous micaschist xenoliths, and small elongated biotite-rich tonalite and vaugnerite enclaves restricted to this biotite granite (Weisbrod et al. 1980). The preferred orientation of these mafic enclaves is consistent with the mineral fabric of the granite (Fig 2a). In the eastern part of the pluton, the previously-mentioned granitic dykes and sills are common within the micaschist country rocks (Fig. 2b).

All leucogranite facies share a common mineral composition of quartz, plagioclase, Kfeldspar, zircon, apatite, monazite and xenotime. Muscovite and sericite grains are the dominant accessory phases. Some secondary minerals are related to the alteration of feldspar and micas. Few micro-scale Ti-Fe oxides coexist either as grains included in mica, feldspar and monazite, or as trails near thin brittle fractures probably infilled during post-magmatic fluid circulation. Besides these assemblages, the three main facies of the pluton exhibit distinctly different grain sizes and a relative abundance of micas, thus presenting a significant microstructural variability.

Texturally, the biotite-rich facies shows weak evidence of plastic deformation at outcrop scale. Some sample collected near local brittle faults exhibit distinct microstructural feature with reference to entire rock micro characteristics. These sample (sites 24, 30 and 37, Fig. 8) show polycrystalline quartz grains with irregular boundaries surrounding plurimillimetre to centimetre-sized K-feldspar megacrysts (Fig. 3a). These K-feldspars, easily seen in outcrops (Fig. 3b), have a well-developed shape-preferred orientation. Field measurements yield a dominant ENE-WSW trend (average of $65^{\circ}$ in strike) with a SE plunge value hardly estimable. Due to a higher muscovite proportion, the middle part of the pluton is more leucocratic than its northern part, corresponding to a finer-quartz-grained granite in comparison to the others (Fig. 3c). Scattered K-feldspar megacrysts altered to sericite are surrounded by plagioclase and chlorite lamellae formed by biotite replacement; this facies does not have a preferred mineral orientation of K-feldspar, even at outcrop scale (Fig. 3d). 
Locally (sites 16, 41, 42 and site 43), quartz porphyroclasts with wavy extinction are surrounded by polycrystalline fine-grained quartz aggregates indicating a dynamic recrystallisation texture. As previously mentioned, this dynamic recrystallisation should have been developed in response to local rock motion. This peculiar feature is different to the dominant texture observed in the granite. Moreover, garnet grains, up to $2 \mathrm{~mm}$ large with small quartz inclusions, are also locally identified. The muscovite-rich facies that occupies the structurally highest part of the pluton differs from the previous one by abundant millimetresize muscovite (Fig. 3e), a low abundance of biotite, and a decrease in quartz grain size. Inclusion-free garnet is a common accessory phase (Fig. 3f).

Based on this petrographic overview, despite the dynamic feature reported in small rock volume distributed all around local brittle fault zones, we argued that the Rocles granite structure indicates fabrics developed at a subsolidus stage during magma crystallisation.

\section{Geochemistry}

Caen-Vachette et al. (1981) performed geochemical analyses of the biotite-rich and muscovite-rich facies. For the present study, additional whole-rock analyses of major elements were made on the intermediate facies. The three granite sub-types share some similar chemical characteristics, such as a high $\mathrm{SiO}_{2}$ content ranging from 70 to $75 \mathrm{wt} \%$ and very low amounts of $\mathrm{TiO}_{2}$ with an upper value of about $0.09 \mathrm{wt} \%$ in the muscovite-biotite middle facies. $\left(\mathrm{Na}_{2} \mathrm{O}+\mathrm{K}_{2} \mathrm{O}\right) / \mathrm{Al}_{2} \mathrm{O}_{3}$ ratios show slight variation between 0.5 and $0.6 \mathrm{wt} \%$. In addition to the above-mentioned similarities, the Rocles massif exhibits a bottom-to-top decrease of $\mathrm{Fe}_{2} \mathrm{O}_{3}$ : the higher $\mathrm{Fe}_{2} \mathrm{O}_{3}$ content of ca. $3 \mathrm{wt} \%$ is found in the biotite-rich facies, whereas intermediate-facies contents are about $1 \mathrm{wt} \%$ and the muscovite-rich facies contains an even lower amount of ca. $0.6 \mathrm{wt} \%$. Rb-Sr dating of the Rocles pluton gave $310 \mathrm{Ma}$ (CaenVachette et al. 1981), but these whole-rock measurements, obtained on several samples from the massif, require a reassessment for each of the three petrographic facies by in-situ techniques on single grains.

\section{New U-Th-Pb ages of the Rocles pluton Analytical procedure}

The detailed analytical procedure is described in Cocherie et al. (1998); the theoretical procedure to reduce the data and calculate the average age from individual ages calculated from individual spot analyses can be found in Cocherie and Albarede (2001) and Cocherie et al. (2005). In the following paragraphs, we describe some recent improvements and stress critical aspects of our calculations. $\mathrm{U}$, Th and $\mathrm{Pb}$ concentrations in monazite were obtained with a Cameca SX50 electron microprobe co-operated by BRGM and ISTO in Orléans. Before chemical analysis, each grain is studied by scanning electron microprobe (SEM) in back-scattered electron mode, in order to avoid micro-inclusions, altered domains and all other components of non-monazite composition. SEM images commonly show heterogeneous domain compositions, which can be related either to discrete age domains or to variations of Th and $U$ composition during the various stages of recrystallisation of monazite within a period of less than $1 \mathrm{Ma}$. The operating conditions are $20 \mathrm{kV}$ and $200 \mathrm{nA}$, which provide average calculated detection limits of 105,130 and $110 \mathrm{ppm}$, for $\mathrm{U}$, Th and $\mathrm{Pb}$, respectively. The major-element composition of monazite remaining similar, we did not consider it necessary to calculate those detection limits for each individual analysis. The detection limits are taken as absolute error. However, monazite is commonly U- and especially Th-enriched, so that a simple statistical error can lead to a very low relative error. As an example, a domain 
containing $13 \mathrm{wt} \%$ of $\mathrm{Th}$ and $1.05 \mathrm{wt} \%$ of $\mathrm{U}$ leads to respective relative errors of 0.1 and $1 \%$. This is actually not realistic because all other error sources, such as standardisation, cannot be taken into account in such a low error calculation. It is the reason why we arbitrarily assumed that, even at high concentration levels, the relative error cannot be $<2 \%$ for $\mathrm{U}, \mathrm{Th}$, and $\mathrm{Pb}$. There is only a limited influence on relatively young samples (e.g. $<300 \mathrm{Ma}$ ), but it may be of major influence for older samples.

After studying several tens of monazite grains, we saw that most of them have Th, $U$ and $\mathrm{Th} / \mathrm{U}$ ratio variations at the $\mu \mathrm{m}$ scale, even for grains homogeneous in age. From a geochemical point of view, the result can be quite surprising because it means that the composition of the melt surrounding the monazite can change significantly during mineral growth. A similar phenomenon is commonly observed on zircon. Such a texture leads to observed episodic mineral growth. These common $\mathrm{Th} / \mathrm{U}$ variations in monazite have led us to propose a geochronological representation $(\mathrm{Th} / \mathrm{Pb} \mathrm{vs}$. U/Pb diagram) suitable only if a single event is recorded, in which case the calculated regression line must fit the related theoretical isochron. Then it is possible to calculate an average age with good precision at the population centroid. Finally, the MSWD calculation must agree with the Wendt and Carl (1991) criteria to certify the statistical significance of the calculated average age. If MSWD and/or the regression line do not satisfy the criteria of a single event, one can use the SambridgeCompston algorithm. The "Unmix ages" option of the ISOPLOT program (Ludwig 2003) allows the deconvolution of several ages for establishing the relationships with the BSE images, thus reducing separately each population before re-using the $\mathrm{Th} / \mathrm{Pb} \mathrm{vs}$. $\mathrm{U} / \mathrm{Pb}$ representation.

\section{Results}

All analysed monazite grains were investigated by SEM. Some are included in feldspar whereas others are found within biotite (Fig. 4). Monazites are free of inheritance, some exhibit few inclusions of various nature (dominantly quartz and biotite are observed) or show a weak chemical zoning mainly related to $U$ and Th contents. The bright zones correspond to Th-rich domains, and conversely the dark ones contain a higher amount of U. EPMA analyses for dating were done directly on thin sections of muscovite-rich and biotite-rich facies. Monazite grains from muscovite-rich and biotite-rich facies gave ages of $324 \pm 4 \mathrm{Ma}(2 \sigma)$ and $325 \pm 4 \mathrm{Ma}(2 \sigma)$ respectively (Fig. 5). The calculated regression lines for both samples are very close to the corresponding theoretical isochron; this indicates that a single event was recorded, taking into account an analytical error of \pm 4 Ma despite the large variation of $\mathrm{Th} / \mathrm{U}$ ratios related to similar large variations in Th and U content. The calculated MSWD are in agreement with such an interpretation. Monazite grains extracted from the intermediate granite facies (biotite-muscovite) and mounted on polished sections were already dated by the same method at $318 \pm 5 \mathrm{Ma}$ (Be Mezeme et al. 2005).

\section{AMS study of the Rocles pluton Sampling}

Among the methods used for characterising geological deformation, several recent studies show that anisotropy of magnetic susceptibility (AMS) is considered as one of the most relevant tools. It examines a wide range of deformation events, including magmatic flow, pluton emplacement, folding as well as all other geological processes that introduce structural organisation or specific petrofrabric assemblies in rocks (e.g. Borradaile and Kehlenbeck 1996; Bouchez 1997; Aranguren et al. 2003). Since planar and linear fabrics are rather 
difficult to determine directly in the field, an AMS study of the Rocles pluton has been carried out. Cores of $25 \mathrm{~mm}$ diameter were collected from 43 sites throughout the three facies of Rocles granite. Samples were taken in situ with a portable water-cooled gasoline drill. The cores were oriented by magnetic compass and a clinometer; GPS positions were recorded as well. Weather permitting, a sun compass was also used to correct the magnetic azimuth. The average difference between solar and magnetic azimuths is about $1.9 \pm 6.4^{\circ}$, which was applied to correct the core orientations that were only measured by magnetic compass. In the laboratory, cores were cut into pieces of $22 \mathrm{~mm}$ length. Subsequently, the magnetic properties of each specimen were measured.

\section{Magnetic mineralogy}

In order to characterise the magnetic mineralogy of our collection, transmitted-light microscopic investigations, isothermal remanent magnetisation (IRM) analyses, and thermalmagnetic experiments were carried out. Three representative cores from the three granite subtypes (ROC24, ROC46 and ROC11) underwent progressive magnetisation from 10 to 1,500 $\mathrm{mT}$ generated by a pulse magnetiser (IM30). IRM values were measured with a JR5A after each magnetisation. The results (Fig. 6a) show similar magnetic characters among the three facies: generally weak IRM $(<0.045 \mathrm{~A} / \mathrm{m})$ with a relatively rapid increase of IRM before $150 \mathrm{mT}$, then a progressive increase until 1,500 $\mathrm{mT}$. This observation suggests that these granitic rocks contain mainly paramagnetic minerals and a small proportion of ferromagnetic minerals, such as magnetite and probably hematite. Thermal magnetic experiments (K vs. T) were performed by a KLY3 Kappabridge coupled with a CS3 furnace. These experiments produce an irreversible variation of magnetic susceptibility. For the heating procedure, low and progressive decreases of magnetic susceptibility were general features for all three facies, confirming the dominance of paramagnetic minerals in our collection (Fig. 6c, d). The important increase in magnetic susceptibility during cooling reveals a remarkable mineral change, probably due to the transformation of some biotite or ilmenite to titano-magnetite.

\section{AMS measurements}

Magnetic susceptibility was measured with a low-field KLY3 kappabridge susceptibility meter, characterised by a high sensitivity (around $10^{-9} \mathrm{SI}$ ) and by continuous measurements in each plane orthogonal to the main x, y and z axes. Susceptibility values $K_{\max }, K_{\text {int }}$ and $K_{\min }$, corresponding to the three main axes of the magnetic-susceptibility ellipsoid, and bulk susceptibility $K_{\text {mean }}$ were determined. The magnetic lineation is represented by $K_{\max }$ axes; $K$ $\min$ axes correspond to the magnetic-foliation poles determined by planes containing $K_{\max }$ and $K_{\text {int }}$ axes. Linear and planar anisotropy degrees are then given by $L=K_{\max } / K_{\text {int }}$ (Balsley and Buddington 1960) and $F=K$ int $/ K$ min (Stacey et al. 1960), respectively. Using Jelinek's definitions (1981), the anisotropy degree (P) and shape parameter (T) are calculated.

The main magnetic-susceptibility results of the studied rocks are listed in Table 1. The three facies of the granite pluton generally yield low magnetic susceptibility with values varying from 12 to $120 \times 10^{-6}$ SI (Fig. 7 a, Table 1) and an average of $58.0 \pm 3.4 \times 10^{-6}$ SI. The muscovite-rich facies shows a weaker susceptibility of $35.0 \pm 2.3 \times 10^{-6}$ SI and the biotiterich one has the higher value of $85.0 \pm 2.6 \times 10^{-6} \mathrm{SI}$. These results corroborate our thinsection observations of the small proportion of ferromagnetic minerals found in our collection, and confirm the weak contribution of these minerals to AMS measurements. In other words, micas - mostly biotite- can be considered as the main carrier of magnetic susceptibility. Most sites show an anisotropy degree $(\mathrm{P})$ lower than 1.1 with an average value of $1.07 \pm 0.03$ (Fig. $7 \mathrm{~b}$ ). The form parameter $(\mathrm{T})$ value ranges from -0.15 to 0.68 . More than $80 \%$ of sites present positive $\mathrm{T}$ values, indicating a dominance of the oblate shape with respect to the prolate one (Fig. 7b; Table 1). Figure 8 shows the three main axes of the 
magnetic-susceptibility ellipsoid $\left(K_{\max }, K_{\text {int }}\right.$ and $K_{\min }$ ) defined from the 43 sites on a lowerhemisphere equal-area projection with corresponding geographic position of each site. At least three configurations ( $a, b$ and $c$ ) can be distinguished: (a) Almost all sites of biotite-rich granite provide stereoplots with main axes forming distinct groups (e.g. Roc3, Roc31; Fig. 8). These sites show weak dispersion with moderate $\alpha_{95}$ values (Table 1). Such a well-defined gathering of axes indicates a reliable determination of trend and dip of magnetic foliation as well as magnetic lineation. (b) Both biotite-muscovite and muscovite-rich facies yield $K_{\max }$ axes that cannot be distinguished at a $95^{\circ}$ confidence level, but the $K_{\min }$ axes are scattered. (c) The last configuration corresponds to a scattered distribution of all three main axes with a poorly defined foliation and lineation (e.g. Roc23, Roc43). These heterogeneously distributed axes, even in a single site, cannot be used to establish the global pattern of ASM fabrics for the entire pluton. However, such sites are rare and are probably due to a locally restricted deformation process, distinct from the general trend related to the prevailing tectonic events experienced by the Rocles pluton.

Figure 9 illustrates the magnetic lineation pattern. Apart from a few sites with poorly defined lineation, especially when approaching the granite margins or along faults within the granite, most of sites show an ENE-WSW trend with an average strike of about $70^{\circ}$ and a subhorizontal plunge (Fig. 9a). Moreover, in addition to the dominant ENE-WSW trend, a WNW-ESE trend of the magnetic lineation can also be observed.

The magnetic foliation, defined by the $K_{\max }-K_{\text {int }}$ plane, shows a more complicated pattern. In terms of orientation, two main foliation groups can be distinguished. The main group, corresponding to the general trend, reveals a SE plunge of the foliation with an average dip angle of about $45^{\circ}$. More than $80 \%$ of the sites belong to this group (Figs.8, 10). The second group, which corresponds to the sites near the contact of the pluton with country rocks, presents variable foliation orientation, such as Roc13, 12, 19, 21, 22 and 23 (Figs. 8, 10). A few sites present a poorly defined foliation with dispersed $K_{\text {min }}$ distribution, such as sites 6,14 (Fig. 8). It is worth noting that the foliation pattern is unrelated to the petrological facies discussed above, since similar orientations are found whatever the facies. Therefore, the AMS-fabric development in each facies can be considered as a synchronous.

\section{Discussion}

Based on the petrographic observations and AMS measurements carried out on the Rocles pluton, we conclude that micas, especially biotite, are the main carrier of magnetic susceptibility. In addition, the contribution from Fe- and Ti-bearing oxides is insignificant. Globally, the planar fabric dominates the linear one, and the NE-SW trend of the magnetic lineation is conspicuous throughout the Rocles pluton. As earlier noted (e.g. Weisbrod et al. 1980) from field observations, the pluton foliation plunges consistently SE in almost the entire pluton. A few sites near the contact with country rocks present a variable foliation orientation, which seems to be controlled by the geometry of the pluton-host rock contact; local heterogeneous deformation during granite emplacement may have developed in the pluton and be responsible for this abnormal trend. To a certain extent, the country rocks may have controlled the deformation around the margins of the granite. An important implication of this control is that foliation patterns may follow the pluton boundaries (Fig. 10). It is worth noting that two sites (Roc15 and Roc31), located within the pluton but near faults, show also different foliation orientations with respect to the general trend (Figs. 8, 10). This anomaly suggests significant fault activity after pluton emplacement. The good consistency of foliation trends throughout the pluton, with a predominance of the oblate shape of the ASM fabric ellipsoid, suggests that this granitic body has a SE plunging laccolithic shape with an average 
dip of $55^{\circ}$. This result agrees with mapping and local field observations (e.g. Palm 1957; Weisbrod 1968).

The present geometry of the Rocles pluton and surrounding rocks is strongly influenced by the uplift of the Velay granite-migmatite dome. This tilted the Rocles pluton to the south or south-east; locally, north of the Prades fault, the metamorphic country rocks are overturned to the south. Thus, the structural pattern of the Rocles pluton inferred from the magnetic fabric determined in this study does not correspond to the initial geometry developed during granite emplacement, but is the result of later reworking. In order to restore the primary structure, the southward dip produced by tectonic deformation after emplacement of the Rocles pluton should be untilted. Previous structural works on the Cévennes micaschists (e.g. Mattauer and Echecopar 1977; Weisbrod et al. 1980; Matte 1986; Faure et al. 2001) show that the regional foliation developed during a subhorizontal top-to-the south ductile shearing. As discussed above, the magnetic foliation, consistent with that of the country rocks, suggests that the Rocles pluton was emplaced like a laccolith, i.e. the current tilt of the Rocles pluton must be corrected assuming that the granite foliation developed with a subhorizontal attitude. The Rocles pluton and its regional host rocks experienced a bulk rigid tilting to the SE from an initial flat-lying geometry, due to uplift of the Velay dome around $300 \mathrm{Ma}$. Tilt correction is done by using the present AMS mean foliation trend and dip of $55^{\circ} \mathrm{N}$ and $68^{\circ} \mathrm{SE}$, respectively (Fig. 10a). The probable pre-Velay-dome geometry of the Rocles pluton is inferred from rotation of the mean foliation plane to the horizontal position. This restoration requires a single tectonic correction, which seems more realistic according to previous structural analyses (Mattauer and Echecopar 1977; Faure et al. 2001). The corresponding restored magnetic lineation becomes $75^{\circ} \mathrm{N}$ in strike. Even if the difference yielded by the restoration does not exceed $5^{\circ}$, this geometric reconstruction of the AMS data provides useful information on the structural influence of the Velay dome on the final geometry of the Cévennes area.

It must be kept in mind that this correction remains a crude estimate since, in spite of several structural studies (e.g. Ledru et al. 2001 and references therein), the exact and quantitative knowledge of the strain mechanism that led to the formation of the Velay dome, namely diapiric uprise, upright buckling, gravitational collapse, etc, remains largely unsettled. Nevertheless, this qualitative estimate agrees with previous regional data. Extensive structural and AMS studies of the Middle Carboniferous plutons exposed in the southeastern Massif Central show the development of a conspicuous NW-SE to E-W trending AMS and mineral lineation (Faure 1995; Talbot et al. 2000, 2004). Moreover, in the Borne pluton, which is the closest one to the Rocles massif and where any tilt related to the Velay dome cannot be recognised, the mineral lineation trends E-W (Fig. 1a). The tectonic evolution of the study area is summarised in Fig. 11. During the Middle Carboniferous, the Cévennes area experienced top-to-the-south shearing and nappe stacking coeval with amphibolite facies metamorphism. As in other parts of the Massif Central, post-orogenic extension was accommodated by top-to-the-east shearing. Some thrust contacts were reworked as low-angle ductile normal faults. At that time, around 325-310 Ma, according to our new dating, the Rocles leucogranite pluton was emplaced as a laccolith along the reworked contact. Finally in Late Carboniferous time, the emplacement of the Velay dome was responsible for the southward tilt of the previous architecture. 


\section{Conclusions}

AMS measurements of the three petrological facies of the Rocles leucogranite pluton show a good consistency of the magnetic foliation with the regional foliation of Cévennes metamorphic rocks. In spite of some irregularities encountered in sites close to the pluton border or to some faults where the foliation curves, the magnetic foliation is homogeneous throughout the pluton. The sheet-like shape of the intrusion developed synchronously to the extensional tectonic event undergone by the country rock around 325-310 Ma, after crustal thickening. Both leucogranite and host rocks were then reworked by the upliftof the Late Carboniferous Velay dome at ca. $300 \mathrm{Ma}$. This suggests that the present orientation of the magnetic fabric (foliation and lineation), must have been deviated from its initial position. Qualitative restoration of the ASM lineation before the emplacement of the Velay dome suggests an initial $\mathrm{N} 75^{\circ} \mathrm{E}$ strike, which is consistent with the extension-related stretching lineation trend common in the Cévennes area. Thus, the Rocles leucogranite appears to be a laccolith emplaced during extensional tectonics resulting from a post-thickening evolution of the Variscan Belt in the French Massif Central.

\section{Acknowledgements}

This study has been supported by P. Rossi and the "Carte Géologique de la France" programme at BRGM (French Geological Survey). The Conseil Régional du Centre is acknowledged for financial support. The authors would like to acknowledge the Institut des Sciences de la Terre d'Orléans (ISTO) for providing analytical facilities.

\section{References}

Aranguren A, Cueves J, Tubia JM, Roman-Berdiel T, Casas-Sainz A, Casa-Ponsati A (2003) Granite laccolith emplacement in the Iberian arc: AMS and gravity study of the La Tojiza pluton (NW Spain). J Geol Soc 160:435-445

Balsley JR, Buddington AF (1960) Magnetic susceptibility anisotropy and fabric of some Adirondack granites and orthogneisses. Am J Sci 2:6-20

Barbey P, Marignac C, Montel JM, Macaudiere J, Gasquet D, Jabbori J (1999) Cordierite growth textures and the conditions of genesis and emplacement of crustal granitic magmas: the Velay granite complex (Massif Central, France). J Petrol 40:1425-1441

Be Mezeme E, Cocherie A, Faure M, Legendre O, Rossi P (2005) Electron microprobe monazite geochronology: a tool for evaluating magmatic age domains, example from Variscan French Massif Central migmatites and granitoids. Lithos 87:276-288

Be Mezeme E, Faure M, Cocherie A, Chen Y (2005) In situ chemical dating of tectonothermal events in the French Variscan Belt. Terra Nova 17:420-426

Bingham C (1964) Distribution on a sphere and on the projective plane. Ph.D. thesis, Yale University Borradaile GJ, Kehlenbeck MM (1996) Possible cryptic tectono-magnetic fabrics in 'post-tectonic' granitoid plutons of the Canadian Shield. Earth Planet Sci Lett 137:119-127 
Bouchez JL (1997) Granite is never isotropic: an introduction to AMS studies in granitic rocks. In: Bouchez JL, Hutton DHW, Stephen WE (eds) Granite: from segregation of melts to emplacement fabrics. Kluwer Academic Publishers, Dordrecht, pp 95-112

Brown M, Solar GS (1998) Granite ascent and emplacement during contractional deformation in convergent orogens. J Struct Geol 20:1365-1393

Caen-Vachette M, Couturié JP, Fernandez A (1981) Age westphalien du granite de Rocles (Cévennes, massif Central Français). C R Acad Sci Paris II 293:957-960

Caron C (1994) Les minéralisations $\mathrm{Pb}-\mathrm{Zn}$ associées au Paléozoïque inférieur d'Europe méridionale. Traçage isotopique $\mathrm{Pb}-\mathrm{Pb}$ des gîtes de l'Iglesiente ( $\mathrm{SW}$ Sardaigne) et des Cévennes et évolution du socle encaissant par la géochronologie U-Pb, ${ }^{40} \mathrm{Ar}-{ }^{39} \mathrm{Ar}$ et $\mathrm{K}-\mathrm{Ar}$. Ph.D. thesis, University of Montpellier II, p 288

Cocherie A, Albarede F (2001) An improved U-Th-Pb age calculation for electron microprobe dating of monazite. Geochim Cosmochim Acta 65:4509-4522

Cocherie A, Legendre O, Peucat JJ, Kouamelan AN (1998) Geochronology of polygenetic monazites constrained by in situ electron microprobe Th-U-total $\mathrm{Pb}$ determination: implications for lead behaviour in monazite. Geochim Cosmochim Acta 62:2475-2497

Cocherie A, Be Mezeme E, Legendre O, Fanning CM, Faure M, Rossi P (2005) Electronmicroprobe dating as a tool for determining the closure of Th-U-Pb systems in migmatitic monazites. Am Mineral 90:607-618

Duguet M, Faure M (2004) Granitoid emplacement during a thrusting event: structural analysis, microstructure and quartz c-axis patterns. An example from Hercynian plutons in the French Massif Central. J Struct Geol 26:927-945

Duthou JL, Cantagrel JM, Didier J, Vialette Y (1984) Paleozoic granitoids from the French Massif Central: age and origin studied by ${ }^{87} \mathrm{Rb} /{ }^{87} \mathrm{Sr}$ system. Phys Earth Planet Inter 35:131144

Faure M (1995) Late orogenic Carboniferous extension in the Variscan French Massif Central. Tectonics 14:132-153

Faure M, Leloix C, Roig JY (1997) L'évolution polycyclique de la chaîne hercynienne. Bull Soc Géologique Fr 1686:3-14

Faure M, Charonnat X, Chauvet A, Chen Y (2001) Tectonic evolution of the Cévennes paraautochthonous domain of the Hercynian French Massif Central and its bearing on ore deposits formation. Bull Soc Géologique Fr 172:687-696

Faure M, Ledru P, Lardeaux JM, Matte P (2004) Paleozoic orogenies in the French Massif Central. A cross section from Béziers to Lyon. 32nd Int. Geol. Congres Florence (Italy), Field trip guide book, 40pp. freely dowloadable in http://www.apat.gov.it/site/itIT/APAT/FieldtripGuidebooks/pre-congres B22 
Fowler TJ (1994) Sheeted and bulbous pluton intrusion mechanisms of a small granitoid from southeastern Australia: implications for dyke-to-pluton transformation during emplacement. Tectonophysics 234:197-215

Hutton DHW, Dempster TJ, Brown PE (1990) A new mechanism of granite emplacement: rapakivi intrusions in active extensional shear zones. Nature 343:451-454

Jelinek V (1981) Characterization of the magnetic fabric of rocks. Tectonophysics 79:T63T67

Ledru P, Lardeaux JM, Santallier D, Autran A, Quenardel JM, Floc'h J.P., Lerouge G, Maillet N, Ploquin A (1989) Où sont les nappes dans le Massif Central français? Bull Soc Géologique Fr, 8, V 3:605-618

Ledru P, Courrioux G, Dallain C, Lardeaux JM, Montel JM, Vanderhaeghe O, Vitel G (2001) The Velay dome (French Massif Central): melt generation and granite emplacement during orogenic evolution. Tectonophysics 342:207-237

Ludwig KR (2003) Users manual for isoplot/Ex. version 3.00 A geochronological toolkit for Microsoft Excel. Berkeley Geochronology Center. Spec. Pub. 4, p 71

Matte P (1986) Tectonics and plate tectonics model for the Variscan belt of Europe. Tectonophysics 126:329-374

Mattauer M, Echecopar A (1977) Arguments en faveur de chevauchements de type himalayen dans la chaîne hercynienne du Massif Central français. In: Coll. Inter. CNRS, Ecologie et Géologie de l'Himalaya Paris, 1976, CNRS 268, pp 261-267

Montel JM, Marignac C, Barbey P, Pichavant M (1992) Thermobarometry and granite genesis: the Hercynian low-P, high-T Velay anatectic dome (French Massif Central). J Metamorph Geol 10:1-15

Mougeot R, Respaut JP, Ledru P, Marignac C (1997) U-Pb geochronology on accessory minerals of the Velay anatectic dome (French Massif Central). Eur J Mineral 9:141-156

Palm QA (1957) Les roches cristallines des Cévennes médianes, à hauteur de Largentière, Ardèche, France. Ph.D. thesis, University of Utrecht, Geologia Ultraiectana, 3, p 121

Pin C, Duthou JL (1990) Sources of Hercynian granitoids from the French Massif Central: inferences from $\mathrm{Nd}$ isotopes and consequences for crustal evolution. Chem Geol 83:281-296

Roman-Berdiel T, Aranguren A, Cuevas J, Tubia JM (1998) Compressional graniteemplacement model: structural and magnetic study of the Trives Massif (NW Spain). Lithos $44: 37-52$

Scaillet B, Pêcher A, Rochette P, Champenois M (1995) The Gangotri granite (Garhwal Himalaya): laccolithic emplacement in an extending collisional belt. J Geophys Res, [Solid Earth] 100:585-607

Stacey FD, Joplin G, Lindsay J (1960) Magnetic anisotropy and fabric of some foliated rocks from SE. Australia Geofis Pura Appl 47:30-40 
Talbot JY, Chen Y, Faure M, Lin W (2000) AMS study of Pont-de-Montvert-Borne porphyritic granite pluton (French Massif Central) and its tectonic implications. Geophys J Int 140:677-686

Talbot JY, Martelet G, Courrioux G, Chen Y, Faure M (2004) Emplacement in an extensional setting of the Mont Lozère-Borne granitic complex (SE France) inferred from comprehensive AMS, structural and gravity studies. J Struct Geol 26:11-28

Weisbrod A (1968) Les conditions du metamorphisme dans les Cévennes médianes. Comptes rendus de l'Académie des Sciences, Paris, 266, 775

Weisbrod A, Pichavant M, Marignac C, Macaudiere J, Leroy J (1980) Relations structurales et chronologiques entre le magmatisme basique, les granitisations et l'évolution tectonométamorphique tardi-hercynienne dans les Cévennes médianes, Massif Central Français. C R Acad Sci Paris 291:665-668

Wendt I, Carl C (1991) The statistical distribution of the mean squared weighted deviation. Chem Geol (Isot Geosci Sect) 86:275-2 


\section{Figures}

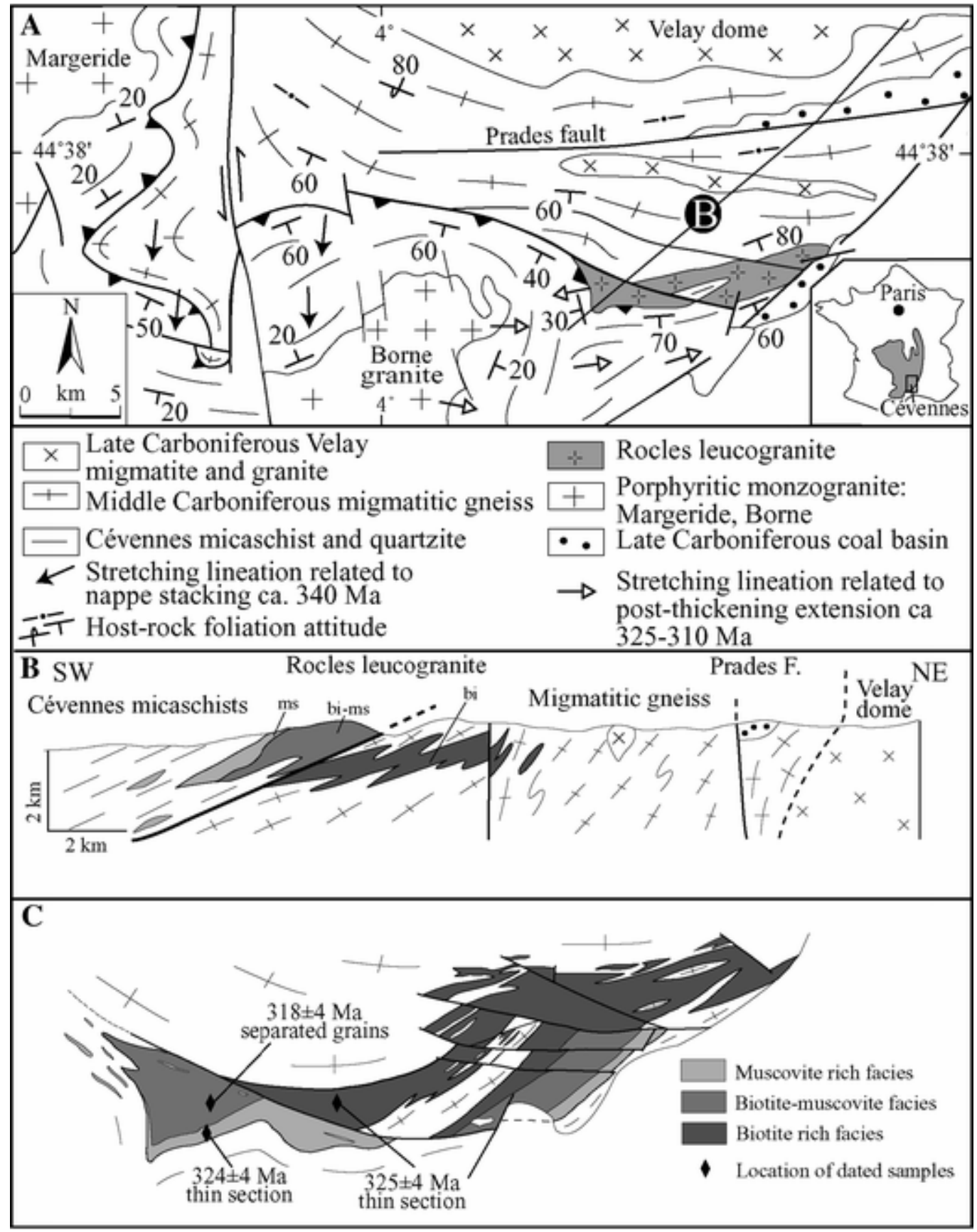

Fig. 1 Geological setting of the Cévennes area in the French Massif Central (insert). a Structural map showing the Rocles, Margeride and La Borne granitic massifs. The map highlights the two stretching lineations related to nappe stacking and post-thickening extension. b Cross section of the study area. Granite shape illustrate magma injections in foliation planes of country rock. c Detail map of the Rocles granite with the three lithological types and location of newly dated samples by EPMA analysis on monazite 

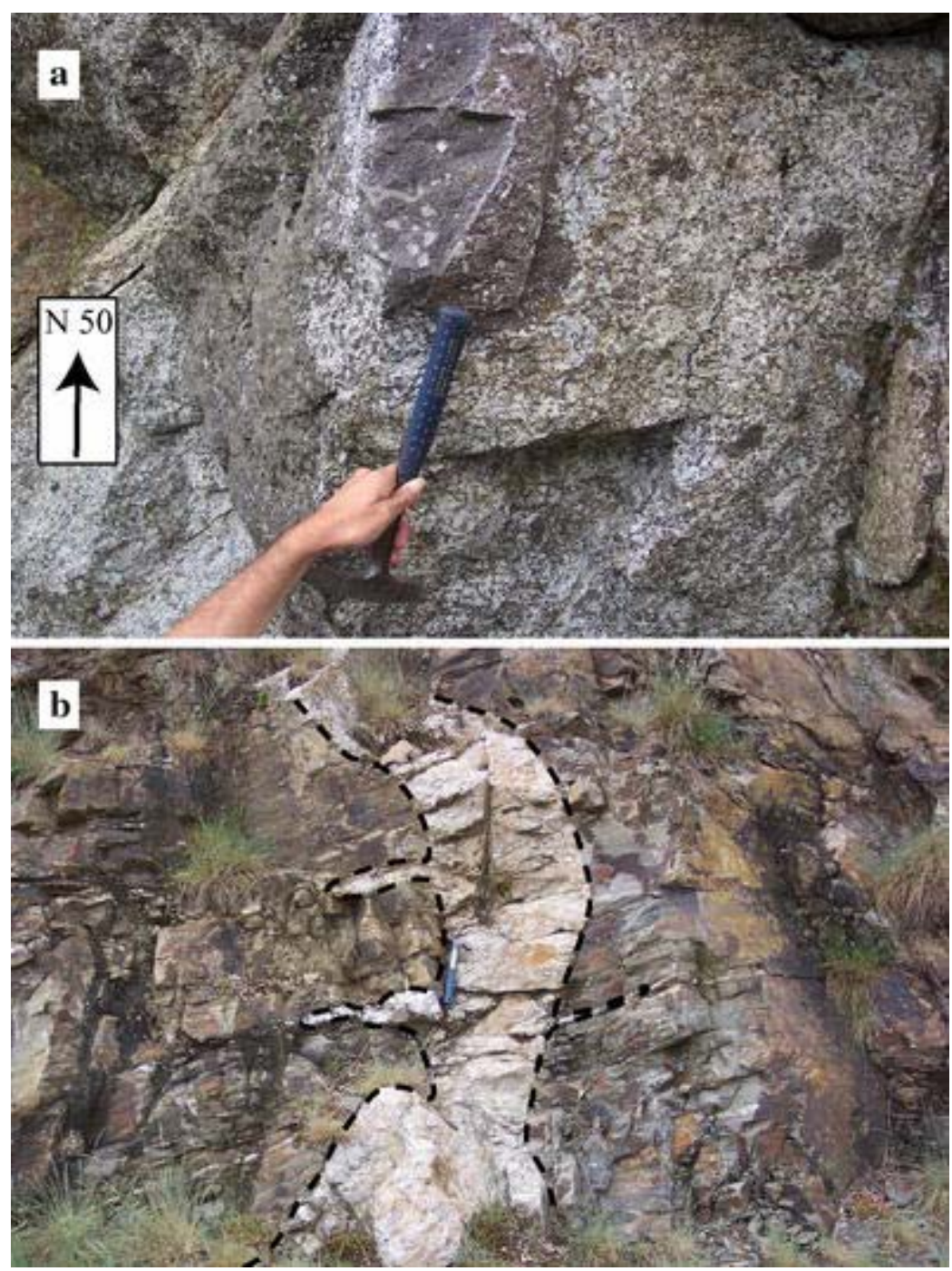

Fig. 2 Field pictures a decimetre sized mafic enclave within biotite-rich facies of Rocles granite. Please note that the AMS fabric measured in the nearby granite is consistent with planar and linear structures inferred from the preferred orientations of enclaves and megacrysts; b leucogranite dyke, and sills intruding micaschist country rocks near the upper contact with the Rocles pluton 

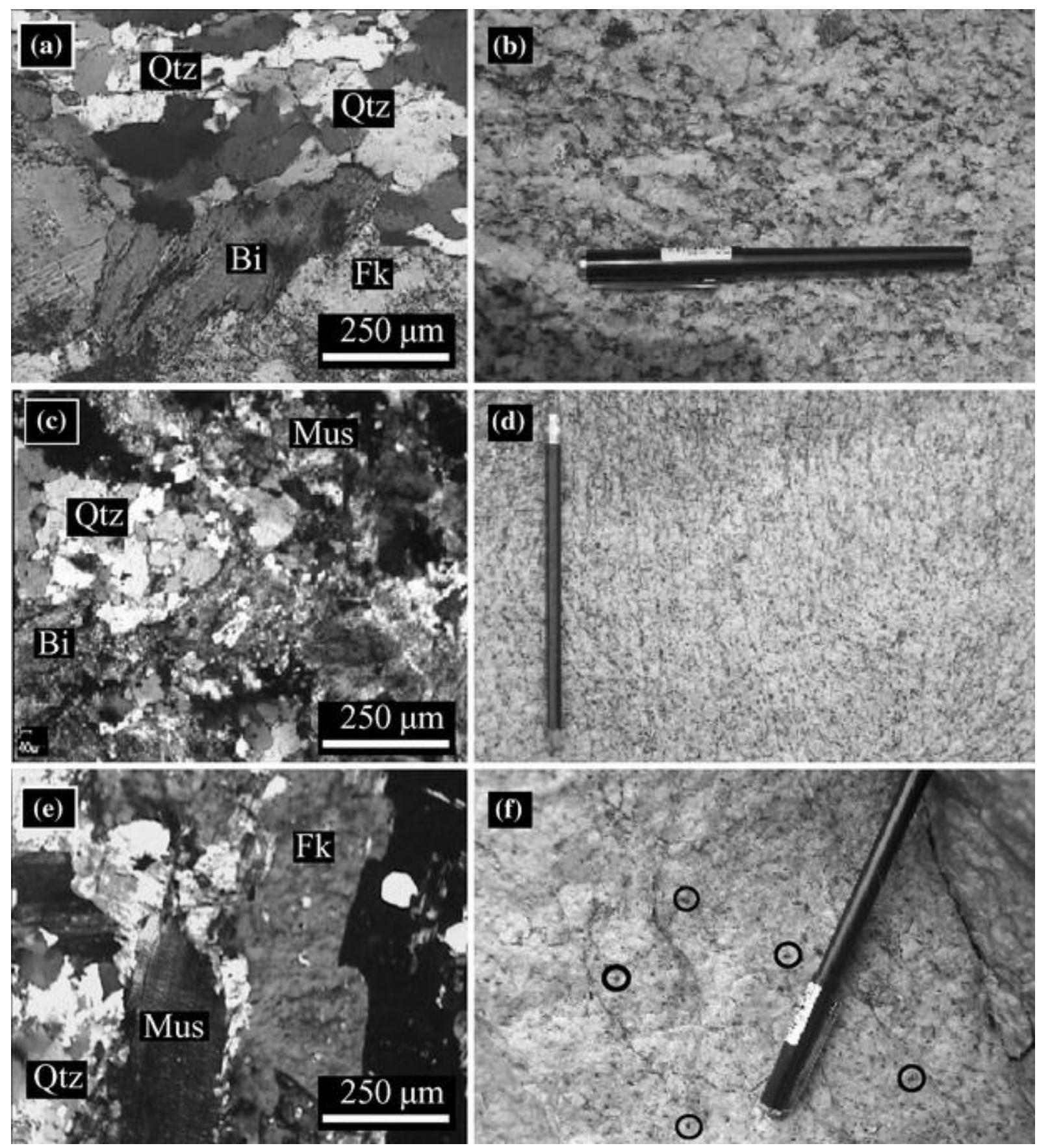

Fig. 3 Macroscopic and microscopic views of the three facies of the Rocles pluton. a and $\mathbf{b}$ Biotite-rich facies showing the weak solid-state deformation and a well-marked K-feldspar preferred orientation. $\mathbf{c}$ and $\mathbf{d}$ Biotite-muscovite intermediate facies. The fabric develops in the subsolidus stage. e and $\mathbf{f}$ Muscovite rich-facies with garnet (circled). For all views Qtz, Bi, Fk, Mus, Gt stand for quartz, biotite, K-feldspar, muscovite, garnet, respectively 


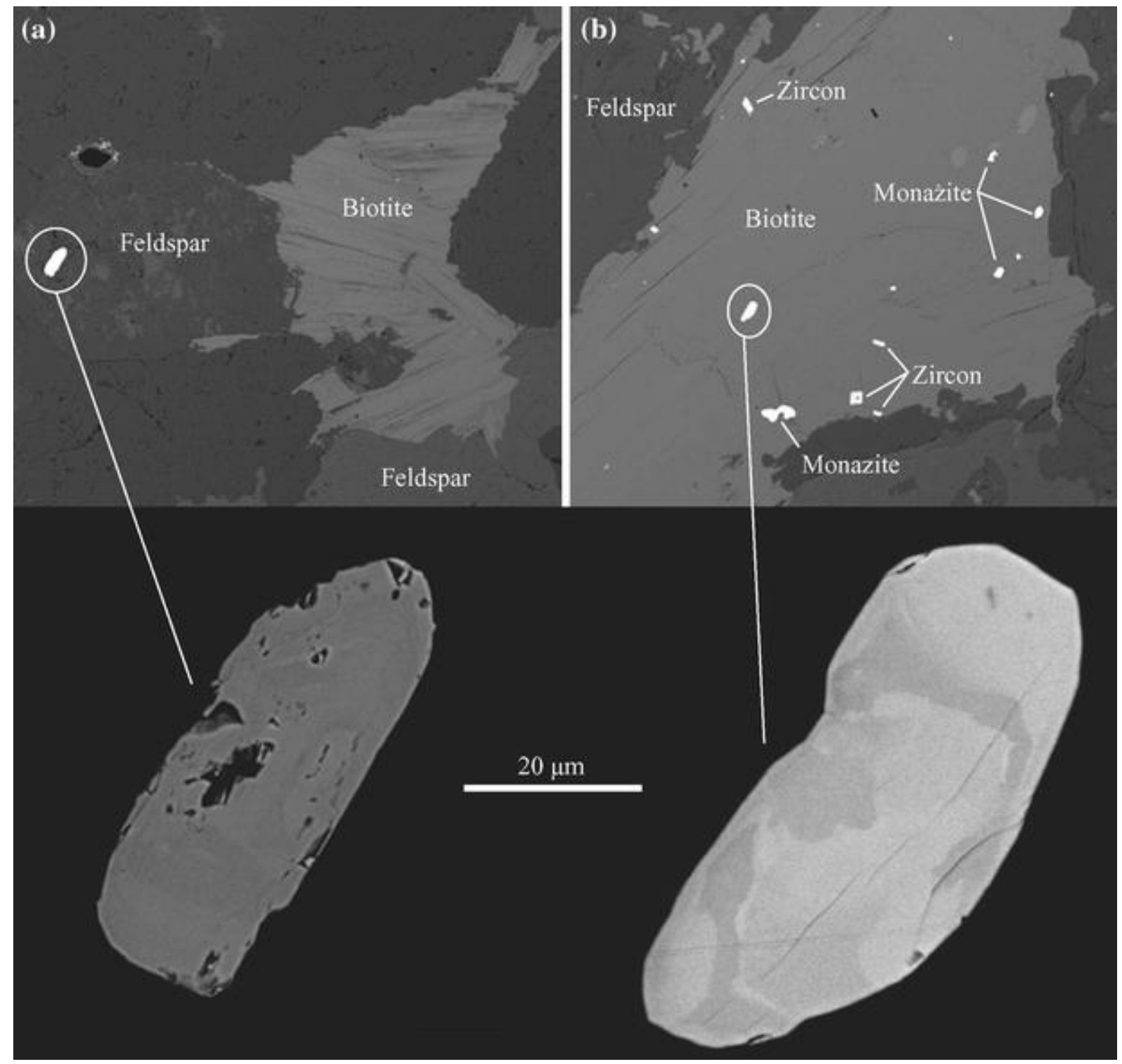

Fig. 4 BSE view of representative monazite grains from the Rocles pluton. The top row images illustrate the main location of monazite grains in relation to the surrounding minerals. Monazite included in biotite exhibits a weak zonation related to Th and $\mathrm{U}$ variations 

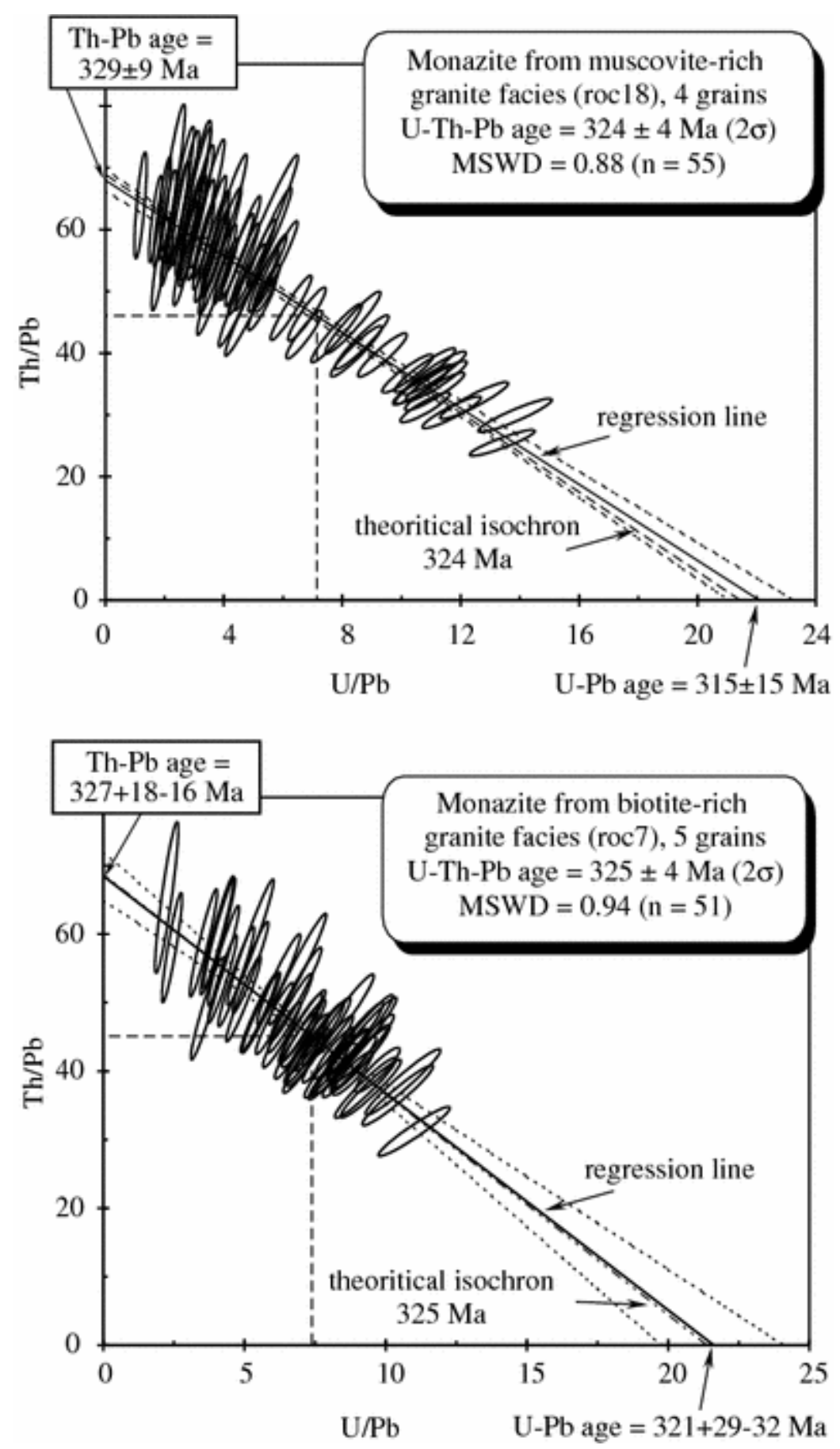

Fig. $5 \mathrm{U} / \mathrm{Pb}$ vs. $\mathrm{Th} / \mathrm{Pb}$-isochron diagrams for monazite from biotite-rich facies and muscoviterich facies of Rocles granite (cf. sample location in Fig. 1). All errors are given at $2 \mathrm{~s}$ level (95\% confidence) 

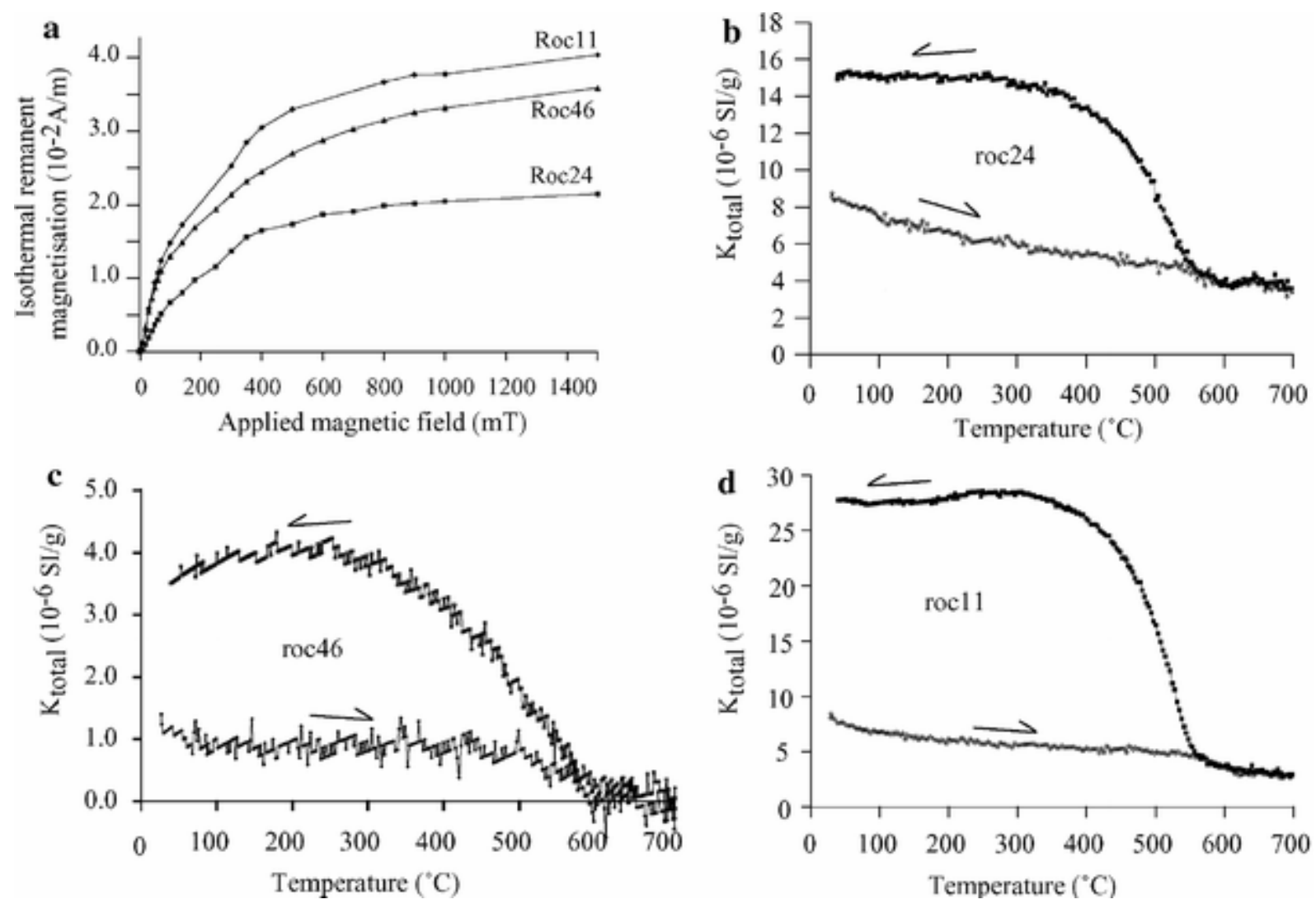

Fig. 6 a IRM diagram of specimens from the three granite facies. The non-linear curves are similar and reflect a few contributions of hematite to the bulk susceptibility. Samples are not saturated even at high intensity of the applied field. $\mathbf{b}, \mathbf{c}, \mathbf{d}$ Representative thermomagnetic curves from 29 to $700^{\circ} \mathrm{C}$ on bulk rock of biotite-rich facies (Roc24), biotite-mucovite facies (Roc46) and muscovite facies (Roc11) respectively 

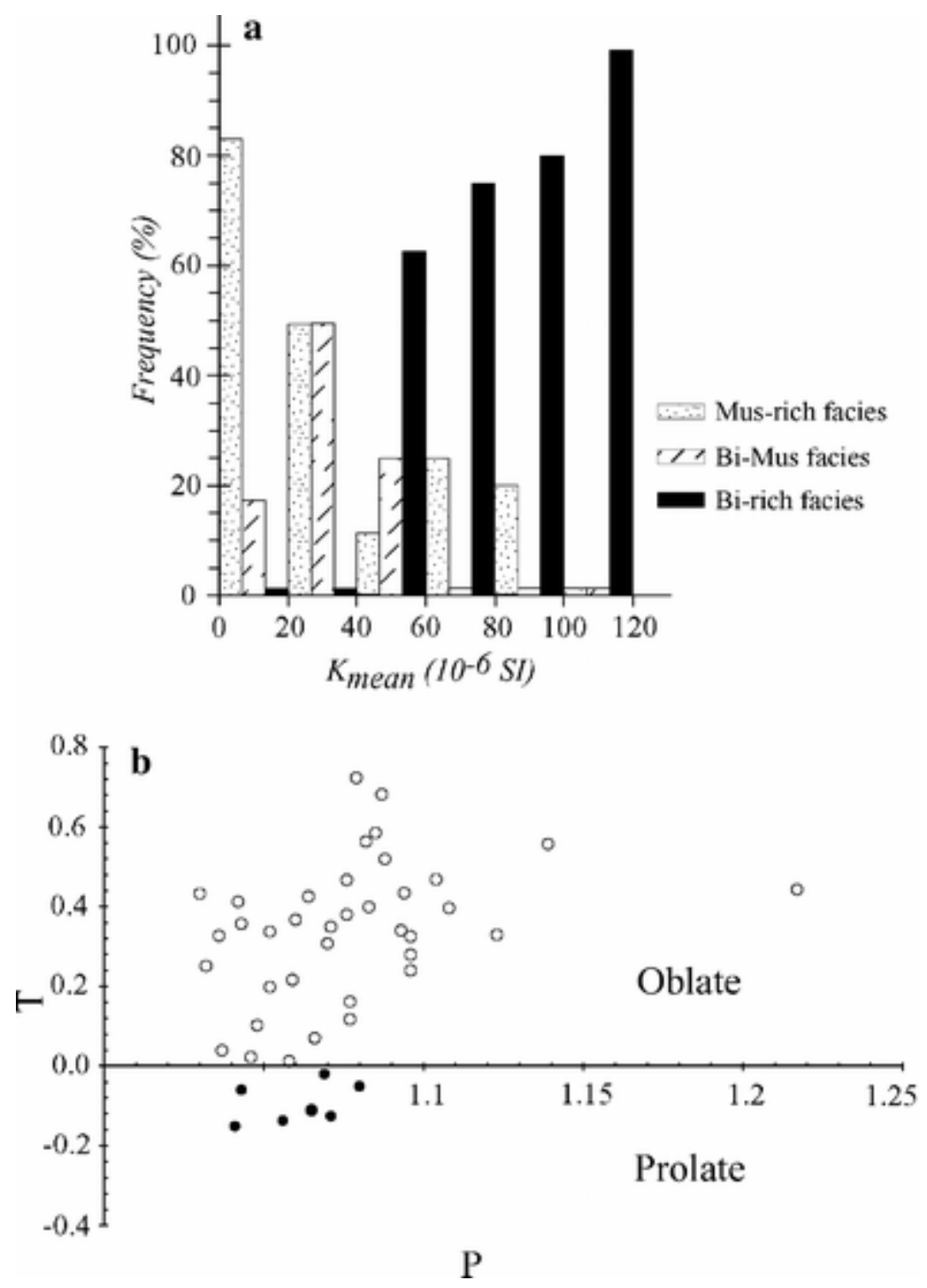

Fig. 7 a Histogram of the mean susceptibility value showing the contribution of each granite facies. b Plot of shape parameter $(T)$ and degree of anisotropy $(P)$. Note the dominant oblate deformation with positive $T$ values. In addition, the samples are characterised by very low anisotropy 


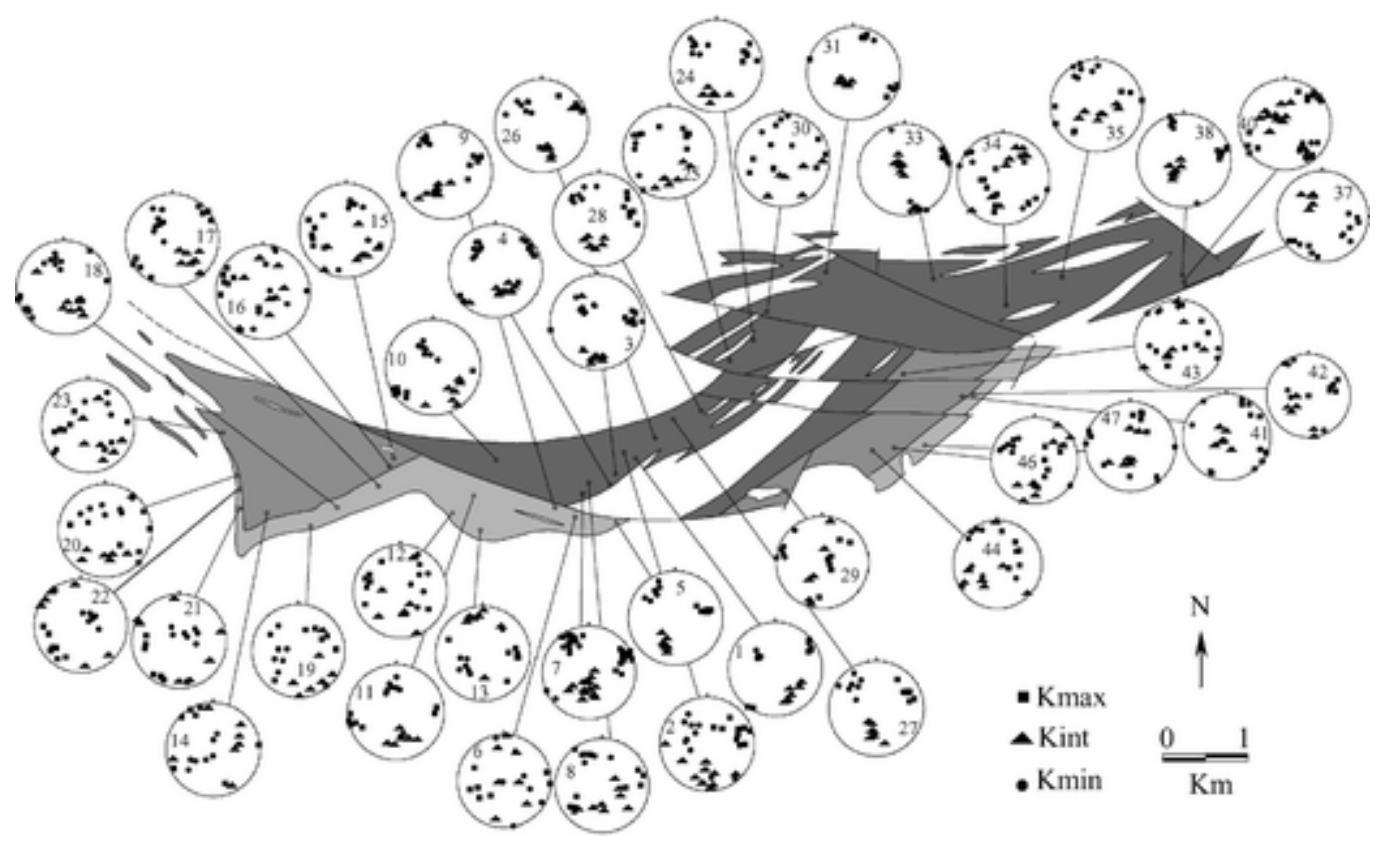

Fig. 8 Equal-area projection of the directions of magnetic susceptibility axes for 43 sites with their geographical location within the Rocles pluton (projection on lower hemisphere)

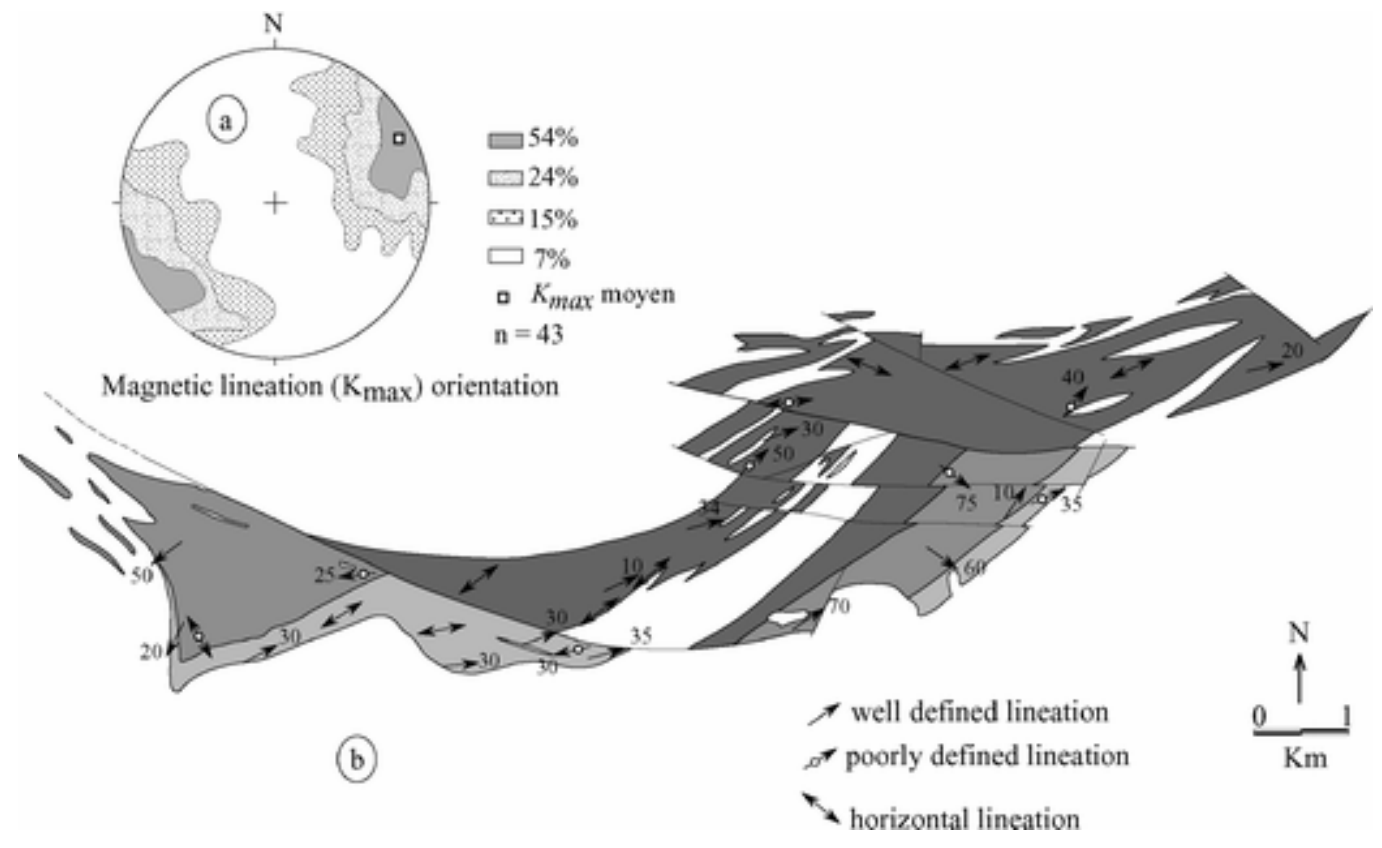

Fig. 9 Structural map of Rocles granite summarising the direction of magnetic lineations with plunge angle. The stereographic diagram shows the mean direction of defined lineations 


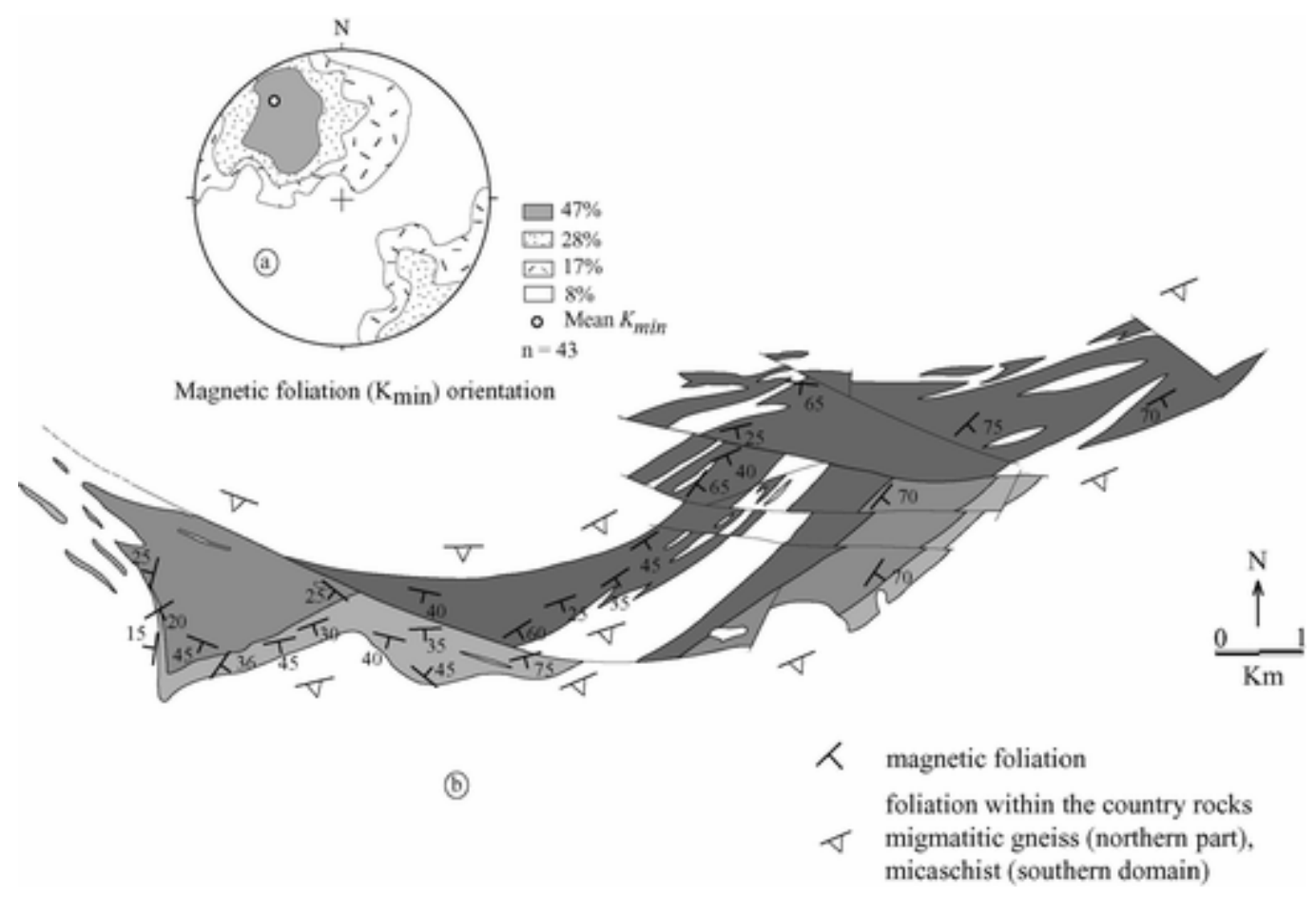

Fig. 10 Sketch map of the Rocles granite showing magnetic foliation with dip angles. The stereographic projection presents the distribution of the minimum main axis $\left(K_{\min }\right)$, which corresponds to the magnetic-foliation pole. Note the similarity between magnetic foliation and mineral foliation in the host rock. Moreover, the preferred planar-mineral orientation in the granite is concordant with AMS measures 


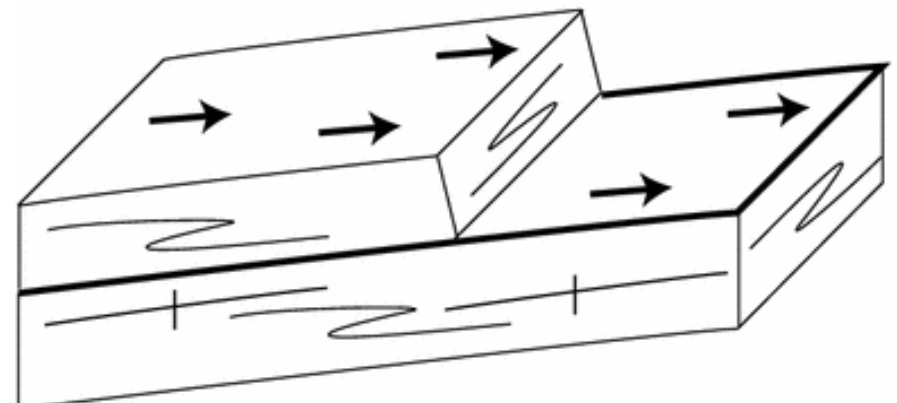

B ca $325-320 \mathrm{Ma}$ - Top-to-the-East extension

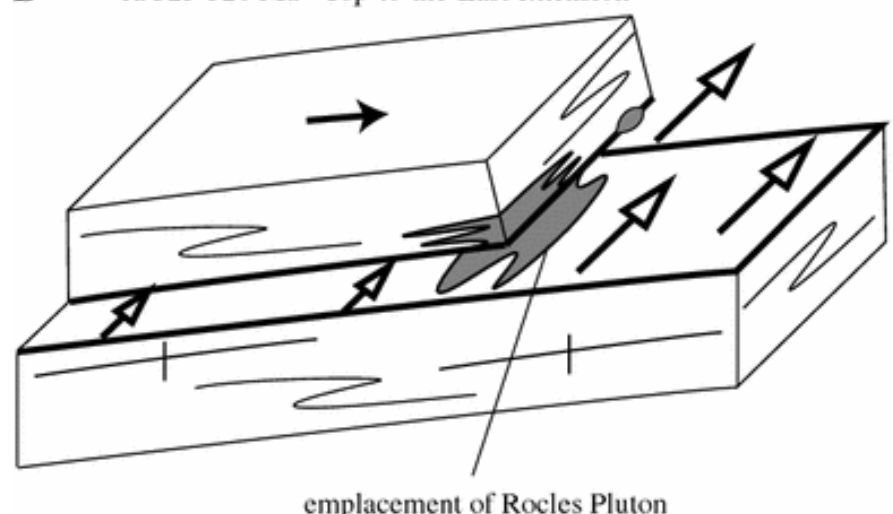

C ca $300 \mathrm{Ma}$ - southward tilting

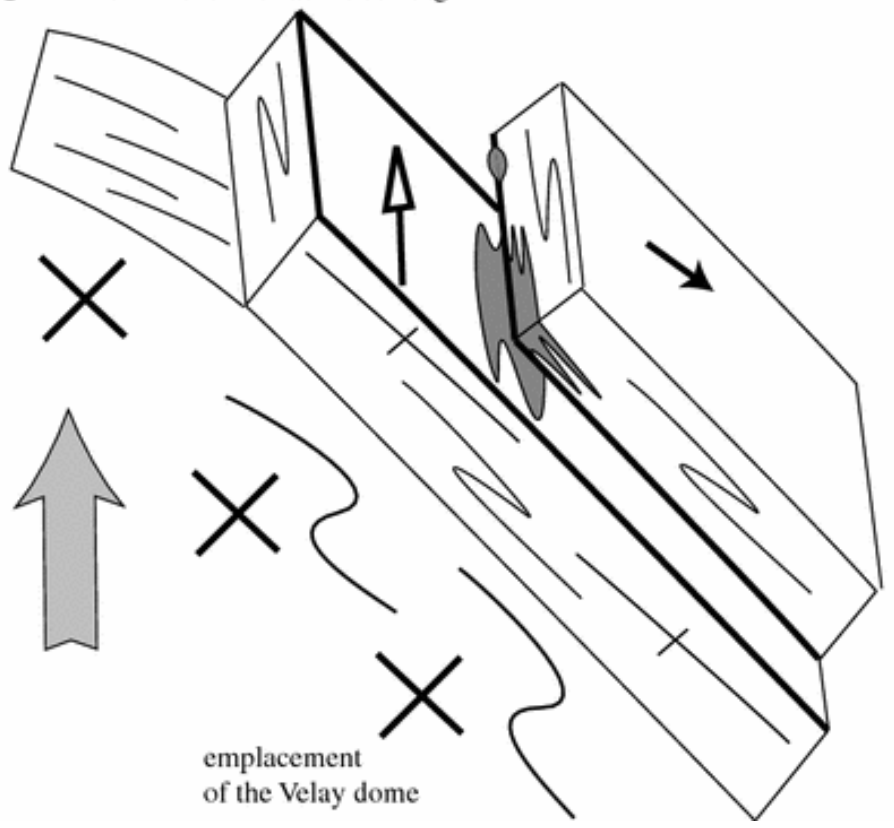

Fig. 11 Schematic sketch of the tectonic evolution of the Rocles pluton. a Middle Carboniferous nappe stacking stage coeval with Top-to-the-south ductile and synmetamorphic shearing. b Post-orogenic extensional tectonics and emplacement of the Rocles pluton as a laccolith along a reworked older tectonic contact. $\mathbf{c}$ Late Carboniferous bulk southward tilting of the Rocles pluton and its host rocks due to the emplacement of the Velay granite-migmatite dome 



\section{Table}

Table 1 Summary of anisotropy of magnetic-susceptibility data

\begin{tabular}{|c|c|c|c|c|c|c|c|c|c|c|c|c|c|c|c|c|}
\hline \multirow{2}{*}{ Site } & \multirow{2}{*}{$n$} & \multirow{2}{*}{$K_{\text {mean }}\left(\times 10^{-6}\right)$} & \multicolumn{4}{|c|}{ AMS parameters } & \multicolumn{2}{|c|}{ Eigenvectors } & \multirow[b]{2}{*}{ Inc } & \multirow[b]{2}{*}{$\alpha_{95 \mathrm{x}}$} & \multirow[b]{2}{*}{$\alpha_{95 y}$} & \multirow[b]{2}{*}{$K_{\text {min }}$} & \multirow[b]{2}{*}{ Dec } & \multirow[b]{2}{*}{ Inc } & \multirow[b]{2}{*}{$\alpha_{95 x}$} & \multirow[b]{2}{*}{$\alpha_{95 y}$} \\
\hline & & & $\mathbf{L}$ & $\mathbf{F}$ & $\mathbf{P}$ & $\mathbf{T}$ & $K_{\max }$ & Dec & & & & & & & & \\
\hline \multicolumn{17}{|c|}{ Bi-rich facies } \\
\hline Roc1 & 6 & 120 & 1.02 & 1.06 & 1.08 & 0.56 & 103 & 51 & 10 & 16 & 2 & 95 & 309 & 52 & 5 & 2 \\
\hline Roc2 & 9 & 101 & 1.03 & 1.07 & 1.10 & 0.33 & 103 & 64 & 27 & 21 & 11 & 98 & 315 & 33 & 69 & 15 \\
\hline Roc3 & 7 & 108 & 1.04 & 1.04 & 1.08 & 0.16 & 103 & 86 & 26 & 18 & 5 & 97 & 314 & 54 & 17 & 12 \\
\hline Roc4 & 8 & 117 & 1.02 & 1.07 & 1.09 & 0.59 & 103 & 55 & 7 & 11 & 8 & 95 & 319 & 38 & 10 & 5 \\
\hline Roc7 & 14 & 60 & 1.03 & 1.07 & 1.09 & 0.43 & 103 & 69 & 21 & 29 & 8 & 96 & 330 & 24 & 13 & 9 \\
\hline Roc8 & 7 & 67 & 1.02 & 1.06 & 1.08 & 0.40 & 103 & 237 & 20 & 20 & 10 & 96 & 338 & 29 & 17 & 9 \\
\hline Roc10 & 6 & 115 & 1.02 & 1.03 & 1.05 & 0.20 & 102 & 234 & 9 & 9 & 5 & 98 & 337 & 56 & 17 & 5 \\
\hline Roc24 & 6 & 101 & 1.02 & 1.04 & 1.06 & 0.22 & 102 & 70 & 30 & 15 & 10 & 97 & 315 & 36 & 13 & 9 \\
\hline $\operatorname{Roc} 25$ & 6 & 103 & 1.02 & 1.04 & 1.05 & 0.34 & 102 & 47 & 48 & 22 & 12 & 98 & 287 & 25 & 28 & 4 \\
\hline Roc26 & 6 & 80 & 1.03 & 1.06 & 1.09 & 0.34 & 103 & 57 & 13 & 19 & 3 & 96 & 316 & 39 & 19 & 11 \\
\hline Roc27 & 6 & 99 & 1.03 & 1.04 & 1.08 & 0.12 & 103 & 60 & 26 & 15 & 4 & 97 & 315 & 28 & 19 & 13 \\
\hline Roc28 & 6 & 92 & 1.02 & 1.05 & 1.07 & 0.35 & 103 & 75 & 34 & 20 & 7 & 97 & 321 & 32 & 20 & 6 \\
\hline Roc30 & 5 & 44 & 1.01 & 1.03 & 1.04 & 0.33 & 101 & 83 & 8 & 32 & 20 & 99 & 349 & 25 & 36 & 15 \\
\hline Roc31 & 5 & 51 & 1.02 & 1.02 & 1.04 & -0.06 & 102 & 112 & 9 & 13 & 4 & 98 & 18 & 21 & 7 & 3 \\
\hline Roc33 & 7 & 110 & 1.02 & 1.03 & 1.05 & 0.10 & 102 & 72 & 7 & 6 & 3 & 98 & 163 & 8 & 16 & 6 \\
\hline Roc34 & 8 & 46 & 1.01 & 1.03 & 1.04 & 0.41 & 101 & 37 & 39 & 27 & 13 & 98 & 305 & 2 & 32 & 11 \\
\hline Roc35 & 6 & 71 & 1.02 & 1.02 & 1.05 & 0.02 & 102 & 246 & 2 & 30 & 16 & 98 & 337 & 15 & 17 & 16 \\
\hline Roc37 & 6 & 96 & 1.02 & 1.06 & 1.08 & 0.47 & 103 & 219 & 22 & 23 & 11 & 97 & 112 & 35 & 20 & 10 \\
\hline
\end{tabular}




\begin{tabular}{|c|c|c|c|c|c|c|c|c|c|c|c|c|c|c|c|c|}
\hline \multirow{2}{*}{ Site } & \multirow{2}{*}{$n$} & \multirow{2}{*}{$K_{\text {mean }}\left(\times 10^{-6}\right)$} & \multicolumn{4}{|c|}{ AMS parameters } & \multirow{2}{*}{\begin{tabular}{|l|} 
Eigenvectors \\
$K_{\max }$ \\
\end{tabular}} & \multirow{2}{*}{ Dec } & \multirow[b]{2}{*}{ Inc } & \multirow[b]{2}{*}{$\alpha_{95 \mathrm{x}}$} & \multirow[b]{2}{*}{$\alpha_{95 y}$} & \multirow[b]{2}{*}{$K_{\text {min }}$} & \multirow[b]{2}{*}{ Dec } & \multirow[b]{2}{*}{ Inc } & \multirow[b]{2}{*}{$\alpha_{95 \mathrm{x}}$} & \multirow[b]{2}{*}{$\alpha_{95 y}$} \\
\hline & & & $\mathbf{L}$ & $\mathbf{F}$ & $\mathbf{P}$ & $\mathbf{T}$ & & & & & & & & & & \\
\hline Roc38 & 6 & 58 & 1.03 & 1.03 & 1.07 & -0.02 & 103 & 78 & 18 & 11 & 3 & 97 & 343 & 14 & 10 & 2 \\
\hline Roc40 & 11 & 59 & 1.02 & 1.07 & 1.09 & 0.52 & 103 & 50 & 2 & 27 & 8 & 96 & 141 & 25 & 12 & 8 \\
\hline \multicolumn{17}{|c|}{ Bi-Mus facies } \\
\hline Roc14 & 6 & 12 & 1.05 & 1.15 & 1.22 & 0.44 & 106 & 330 & 2 & 24 & 9 & 92 & 238 & 53 & 23 & 11 \\
\hline Roc15 & 7 & 51 & 1.03 & 1.03 & 1.06 & 0.01 & 102 & 263 & 27 & 23 & 12 & 98 & 18 & 40 & 17 & 15 \\
\hline Roc16 & 7 & 59 & 1.01 & 1.02 & 1.03 & 0.43 & 101 & 285 & 15 & 23 & 18 & 100 & 17 & 8 & 78 & 14 \\
\hline Roc23 & 6 & 23 & 1.01 & 1.02 & 1.03 & 0.25 & 101 & 254 & 53 & 28 & 15 & 99 & 23 & 25 & 37 & 20 \\
\hline Roc29 & 6 & 39 & 1.01 & 1.07 & 1.09 & 0.68 & 103 & 55 & 71 & 29 & 7 & 96 & 293 & 10 & 19 & 6 \\
\hline Roc41 & 6 & 22 & 1.02 & 1.02 & 1.04 & 0.04 & 101 & 34 & 9 & 22 & 14 & 98 & 124 & 2 & 18 & 2 \\
\hline Roc43 & 6 & 38 & 1.03 & 1.04 & 1.07 & 0.07 & 101 & 126 & 75 & 65 & 14 & 98 & 327 & 14 & 45 & 12 \\
\hline Roc44 & 6 & 28 & 1.03 & 1.04 & 1.07 & -0.13 & 102 & 57 & 40 & 26 & 7 & 98 & 321 & 6 & 21 & 13 \\
\hline Roc46 & 7 & 25 & 1.03 & 1.11 & 1.14 & 0.56 & 104 & 125 & 61 & 68 & 13 & 93 & 302 & 29 & 16 & 9 \\
\hline \multicolumn{17}{|c|}{ Mus-rich facies } \\
\hline Roc5 & 6 & 55 & 1.03 & 1.06 & 1.10 & 0.28 & 104 & 75 & 35 & 9 & 3 & 95 & 324 & 28 & 14 & 6 \\
\hline Roc6 & 6 & 20 & 1.02 & 1.02 & 1.04 & -0.15 & 101 & 256 & 26 & 38 & 14 & 99 & 349 & 6 & 39 & 15 \\
\hline Roc9 & 7 & 76 & 1.01 & 1.07 & 1.08 & 0.72 & 103 & 70 & 28 & 9 & 4 & 96 & 328 & 22 & 6 & 5 \\
\hline Roc11 & 6 & 89 & 1.03 & 1.03 & 1.07 & -0.11 & 103 & 260 & 1 & 21 & 6 & 97 & 351 & 45 & 9 & 7 \\
\hline Roc12 & 6 & 12 & 1.02 & 1.08 & 1.10 & 0.47 & 103 & 288 & 25 & 18 & 4 & 97 & 28 & 20 & 30 & 4 \\
\hline Roc13 & 6 & 33 & 1.02 & 1.06 & 1.08 & 0.38 & 103 & 96 & 29 & 18 & 8 & 96 & 234 & 54 & 15 & 8 \\
\hline Roc17 & 7 & 30 & 1.03 & 1.06 & 1.10 & 0.24 & 104 & 52 & 1 & 14 & 10 & 96 & 320 & 54 & 14 & 8 \\
\hline Roc18 & 7 & 34 & 1.03 & 1.07 & 1.11 & 0.40 & 104 & 241 & 9 & 17 & 4 & 96 & 340 & 46 & 22 & 11 \\
\hline Roc19 & 6 & 18 & 1.02 & 1.04 & 1.06 & 0.37 & 102 & 62 & 31 & 20 & 7 & 98 & 275 & 54 & 38 & 17 \\
\hline
\end{tabular}




\begin{tabular}{|c|c|c|c|c|c|c|c|c|c|c|c|c|c|c|c|c|}
\hline \multirow{2}{*}{ Site } & \multirow{2}{*}{$n$} & \multirow{2}{*}{$K_{\text {mean }}\left(\times 10^{-6}\right)$} & \multicolumn{4}{|c|}{ AMS parameters } & \multirow{2}{*}{\begin{tabular}{|l|} 
Eigenvectors \\
$K_{\max }$ \\
\end{tabular}} & \multirow{2}{*}{ Dec } & \multirow[b]{2}{*}{ Inc } & \multirow[b]{2}{*}{$\alpha_{95 x}$} & \multirow[b]{2}{*}{$\alpha_{95 y}$} & \multirow[b]{2}{*}{$K_{\text {min }}$} & \multirow[b]{2}{*}{ Dec } & \multirow[b]{2}{*}{ Inc } & \multirow[b]{2}{*}{$\alpha_{95 x}$} & \multirow[b]{2}{*}{$\alpha_{95 y}$} \\
\hline & & & $\mathbf{L}$ & $\mathbf{F}$ & $\mathbf{P}$ & $\mathbf{T}$ & & & & & & & & & & \\
\hline Roc20 & 6 & 16 & 1.03 & 1.09 & 1.12 & 0.33 & 102 & 130 & 20 & 48 & 10 & 96 & 11 & 54 & 47 & 12 \\
\hline Roc21 & 6 & 18 & 1.02 & 1.05 & 1.06 & 0.43 & 102 & 208 & 17 & 47 & 7 & 97 & 31 & 73 & 26 & 6 \\
\hline Roc22 & 6 & 33 & 1.04 & 1.04 & 1.08 & -0.05 & 103 & 233 & 25 & 21 & 6 & 97 & 57 & 65 & 13 & 6 \\
\hline Roc42 & 5 & 17 & 1.02 & 1.03 & 1.06 & -0.14 & 102 & 66 & 35 & 10 & 5 & 98 & 285 & 48 & 45 & 3 \\
\hline Roc47 & 6 & 34 & 1.02 & 1.05 & 1.07 & 0.31 & 102 & 22 & 35 & 28 & 12 & 97 & 291 & 1 & 22 & 8 \\
\hline
\end{tabular}

$n$ number of specimens; $K_{\text {mean }}$ mean magnetic susceptibility; $L$ and $F$ stand for magnetic lineation and magnetic foliation anisotropies; $P$ anisotropy degree and $T$ ellipsoid shape parameter; $K_{\max }, K_{\min }$ main axes of magnetic fabrics; Dec, Inc a a 5 , a a 95 declination, inclination, Bingham (1964) bimodal statistics data, respectively 